Portland State University

PDXScholar

\title{
A Study of the Problems of Translation, Rhetorical Analysis, and Translation of a Speech of Mohammed Mossedeq
}

Gholamhosain Janati-Ataie

Portland State University

Follow this and additional works at: https://pdxscholar.library.pdx.edu/open_access_etds

Part of the Speech and Rhetorical Studies Commons

Let us know how access to this document benefits you.

\section{Recommended Citation}

Janati-Ataie, Gholamhosain, "A Study of the Problems of Translation, Rhetorical Analysis, and Translation of a Speech of Mohammed Mossedeq" (1973). Dissertations and Theses. Paper 2034.

https://doi.org/10.15760/etd.2033

This Thesis is brought to you for free and open access. It has been accepted for inclusion in Dissertations and Theses by an authorized administrator of PDXScholar. Please contact us if we can make this document more accessible: pdxscholar@pdx.edu. 
AN ABSTRACT OF THE THESIS OF Gholamhosain Janati-Ataie for the Master of Arts in Speech presented June 22, 1973.

Title: A Study of the Problems of Translation, Rhetorical Analysis, and Translation of a Speech of Mohammed Mossedeq.

APPROVED BY MEMBERS OF THE THESIS COMMITTEE:

$$
\text { Stephor Ā./Kosokoff, Chdirman }
$$

Laprỳ A. Stěward $V \cdot \%$

Theodore G. Grove
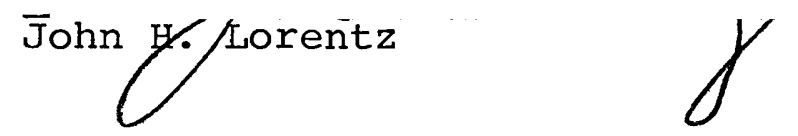

Through the translation and analysis of a major speech, the political thought and rhetorical devices of Mohammed Mossedeq, former Prime Minister of Iran (1951-1953), are examined. Just as cultural and philosophical differences account for many problems in such a translation, so have they led to Mossedeq's being largely misunderstood in the 
West. The study therefore presents a more positive view of Mossedeq, emphasizing his nationalism, which has inspired countless movements toward independence among the Third World nations. Chapters deal with the background of the study, problems of translation (including the semantic and lexical nonequivalences between languages, as well as cultural differences), and significant details from Mossedeq's biography, in addition to the principal translation, rhetorical analysis, and summary chapters. Mossedeq was deeply aware of the political problems of Iran, the most important of which were: (1) the interference of foreign powers, especially England and the Anglo-Iranian Oil Company; (2) the total corruption of the Iranian government; and (3) the lack of political awareness and education of the Iranian people. A major solution to the first problem was Iran's nationalization of her oil resources. The main speech reflects this event and its impact on Iran, as well as on the rest of the world, in the larger context of the need for the Iranians to unite and become conscious of their power and resources.

The speech outlines Mossedeq's political motives, his plans for alleviating Iran's government and people. It also illustrates Mossedeq's charismatic appeal: he was a skilled speaker, one who stirred his audiences, whether they 
were members of the Iranian parliament (Majlis) or illiterate peasants. His language was simple yet highly communicative--and no one before him had ever received such public support in Iran. 


\title{
A STUDY OF THE PROBLEMS OF TRANSLATION, RHETORICAL ANALYSIS, AND TRANSLATION \\ OF A SPEECH OF MOHAMMED MOSSEDEQ
}

by

GHOLAMHOSAIN JANATI-ATAIE

A thesis submitted in partial fulfillment of the requirements for the degree of

\author{
MASTER OF ARTS \\ in \\ SPEECH
}

Portland State University

1973 
TO THE OFFICE OF GRADUATE STUDIES AND RESEARCH:

The members of the Committee approve the thesis of Gholamhosain Janati-Ataie presented June 1973.

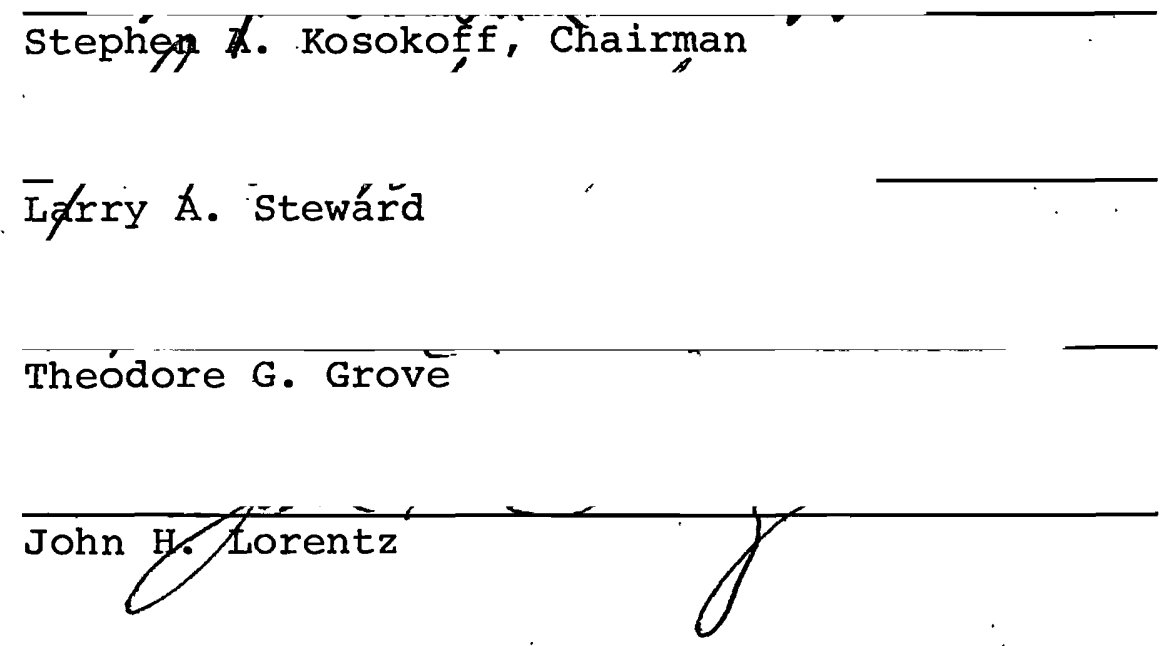

APPROVED :

Robdrt Wogelsang,/Head, Depay/tment of Speech

David̆ T. Clark, Dean of Graduate Studies and Research June 1973 


\section{TABLE OF CONTENTS}

PAGE

PREFACE . . . . . . . . . . . . . . . . . iii

ACKNOWLEDGEMENTS . . . . . . . . . . . . . . iv

CHAPTER

I INTRODUCTION . . . . . . . . . . . . . 1

II. PROBLEMS OF TRANSLATION . . . . . . . . 6

III BIOGRAPHY OF MOHAMMED MOSSEDEQ . . . . . 12

IV TRANSLATION OF A SPEECH BY MOHAMMED

MOSSEDEQ . . . . . . . . . . . 21

V RHETORICAL ANALYSIS . . . . . . . . 43

VI SUMMARY AND CONCLUSION • • • • • • . . 55

BIBLIOGRAPHY. . . . . . . . . . . . . . 62 


\section{PREFACE}

Interest in the problem underlying this study evolved from my introduction to English as a second language. Having come from Iran, a Farsi-speaking land, I soon realized that the most important phenomenon for understanding and communicating among people is language. And being involved constantly in the problems of moving from one language to another, I came to the clear realization that translation is merely interpretation and, when it involves deeper concepts, next to impossible.

Although I make no claims to have solved the basic problems of translation, I do feel--especially since I am bilingual--that I have reached an understanding of some of them, which I hope to pass on to the reader. Much can be gained through comparative study, analysis, and research, including mutual understanding and appreciation, to which this study is dedicated. 


\section{ACKNOWLEDGEMENT}

Words fail me to adequately express the deep gratitude I feel toward the people who have contributed so much to this work.

This is the English version for acknowledging the help of others. However, in Farsi the proper thing to say would be:

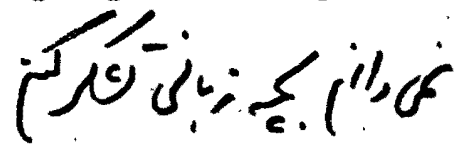

The least I can say is that I was very fortunate to study under such fine faculty members and to have such good friends outside the academic world.

My sincere special thanks go to Dr. Stephen A. Kosokoff. As unnoticeable as it may seem, he taught me a lot. Dr. Theodore G. Grove and Dr. Larry A. Steward scare me with their scientific approach (Methodology and Psychology), but I appreciate them. Professor John H. Lorentz, Middle East Studies Center, speaks my language and has greatly aided me with his knowledge of Iranian history.

Among my friends, I would like to thank Geraldine Topliff for many hours of help, Elaine Evans for the preliminary editing and typing, Firooz and Firoozeh JanatiAtaie for research and typing assistance, Charlotte Cox for the final editing, and Mary $k$. Collins for the final 
typing. For me, happiness is a good friend who knows how to spell in English. And among my friends I wish to. include my books.

I wish also to express my gratitude to the many people who made their personal copies of Farsi sources available to me, and, of course, to those who in their special way were quite encouraging.

Finally, I shall never forget Dr. William Miller. of the University of Nevada, Department of Speech, who inspired me in the world of interpretation. 
CHAPTER I

INTRODUCTION

As 1951 drew to a close, Time magazine's committee for Man of the Year gathered around a big table to make a decision. The choice was not an easy one. There were at least seven nominees, including such world-renowned men as Matthew Ridgway, John Foster Dulles, Harry Truman, Winston Churchill, Dwight Eisenhower, and Douglas MacArthur. Yet the man finally chosen was a far less well-known Iranian statesman, once described by former United States Secretary of State Dean Acheson as,

the character Lob in James Barrie's play Dear Brutus. He was small and frail with not a shred of hair on his billiard-ball head; a thin face protruded into a long beak of a nose flanked by two bright, shoebutton eyes. His whole manner and appearance was birdlike, marked by quick nervous movements as he seemed to jump about on a perch. 1

The man was Mohammed Mossedeg, whose selection Time announced as follows:

In its leadership of the non-communist world, the United States has some dire responsibilities to

${ }^{1}$ Dean Acheson, Present at the Creation: My Years in the State Department (New York: W. W. Norton, 1969); p. 503. 
shoulder. One of them is to meet the fundamental moral challenge posed by the strange old wizard who lives in a mountainous land and who is . . the man of 1951.2

Mohammed Mossedeq's achievements have yet to be studied and assessed objectively. Sources of material on the man and his accomplishments, except for those in the original Farsi language, are few and inadequate. For this reason a rhetorical analysis and careful translation of Mossedeq's historical speeches is of vital importance.

According to Richard W. Cottam in Nationalism in Iran,

That Time magazine, for example, should have chosen. Mossedeq as its man of the year in 1952 seems now to have been almost aberrant. Time's cover story of Mossedeq could hardly have pleased Mossedeq's supporters; but they ignored the story and revelled in the implication of Mossedeq's selection. The choice of Mossedeq was made because he symbolized the emergence in the Middle East of a popular force capable of establishing itself in power.. . Mossedeq's premiership remains extremely significant; both the triumphs and the eventual defeat of Iranian Nationalism need to be surveyed if Iranian nationalism is to be understood. 3

Mossedeq was the first man from the Middle East in 150 years who stood against the world's greatest imperialist power, England. Though his stay in power was short, he made many important contributions to Iran as well as other

2 "Man of the Year: Challenge of the East," Time, January 7, 1952, p. 21 .

${ }^{3}$ Richard W. Cottam, Nationalism in Iran (Pittsburgh: Pittsburgh University Press, 1964), p. 269. 
Third World countries. This is one reason for the interest in Mossedeq displayed by historians and political scientists. 4

The aim of this study is to be objective. Therefore, both the positive and negative aspects of Mossedeq's political contribution will be explored.

On the positive side, Mossedeq is credited as being the man who started the Third World uprising against imperialist powers. Although twenty years have elapsed, Mossedeq is still very popular today in the under-developed countries. In fact, leaders like Castro, Ben Bella, Sukarno, Nkrumah, Nasser, and even Nehru credit Mossedeq for being their inspiration. 5

The negative viewpoint concentrates mainly on Mossedeq's political mistakes and on his being a member of a ruling-class family, as well as on his being fanatically nationalistic or too idealistic. It is suggested that perhaps taking on the major world powers was too big a task for him.

In spite of the claims of either his opposition or his followers, history shows that whatever Mossedeq said he acted upon. Mossedeq had much convincing to do, and despite

${ }^{4}$ Ibid., pp. 259-285.

${ }^{5}$ M. Makan, A Look Into the Life of Dr. Mohammed Mossedeg (n.p.: Iranian National Front in Europe, 1964), p. 4 . 
all the problems that confronted him, he was immensely persuasive.

According to Aristotle, "The modes of persuasion are the only true constituents of the art [rhetoric]: everything else is merely accessory." 6 In this study, we are concerned with the oratory of a major nationalist leader as a means of persuasion.

What Mossedeq stood for is to be found in the total substance of his speeches made across half a century: Iran for the Iranians; nationalization of oil throughout Iran; giving no concession to any foreign government or corporation; elimination of corruption within the Iranian government at all levels; and correction and enforcement of election laws nationally as well as locally. The speeches chosen for translation in this study illustrate Mossedeq's rhetoric concerning these issues.

Through careful translation, and investigation of the strategies and tactics of his speeches, we hope to acquire an understanding of Mossedeq's use of rhetorical devices. A study of Mossedeq's rhetoric may also provide insight into the phenomenon of motivating the masses to action. 7

${ }^{6}$ Aristotle Rhetoric 1. 1354al. 13.

7 This phenomenon was witnessed by Richard w. Cottam during his first stay in Iran in 1951-52. He notes in Nationalism in Iran that "the first period was the apex of the Mossedeq era, and the Iran I saw had much verve" (p. vii). 
Anti-Mossedeq sources are plentiful. However, the aim of this study is not to add to those sources. On the contrary, the emphasis throughout is on bringing to light, through translation, the pro-Mossedeq literature. This emphasis is intentional, since much can be learned through comparative studies. That is, the propaganda of antiMossedeqists permit the analyst to reconstruct their image of Mossedeq, while the vigorous Mossedeqist publications provide an excellent base of comparison.

This study attempts to maintain an analytical approach. However, avoiding making value judgments on Mossedeq's political ends and the means to them is not an easy task. But the greatest difficulty to surmount in a study such as this one is the difference in cultural backgrounds--in this case, between East and West. As Charles Malik of Lebanon has commented on the Western attitude toward the Near East,

The Western world is responsible for the situation in the Near East on every level of that situation ... . Strategy, commerce, exploitation, securing an imperial route: these were why the West for the most part came to the Near East, not because it loved us. Add to this the immense racial arrogance of modern Europe. The West has not been true to itself $\delta$ and therefore it could not have been true

${ }^{8}$ Charles Malik, "The Near East: The Search for the Truth," Foreign Affairs, January 1952, pp. 261-263. 
CHAPTER II

\section{$\checkmark$}

PROBLEMS OF TRANSLATION

Experts have established that a completely accurate translation is impossible. They may disagree on the merits of various translations, or the method to be used, but the majority agree with savory that "all translations seem . . . to be simply an attempt to solve an insoluble problem." 1

In this chapter, however, we are dealing with a certain perspective on the problems of a particular translation rather than assembling facts about it. We are not concerned with the ultimate psychological basis of the work, but rather with an attempt to at least touch upon some of the actual, descriptive, or cultural problems of translating it.

The main purpose of this chapter, then, is to show what are conceived by this translator as problems. In reality, for instance, I find it very uncomfortable to hide my biases, because no matter how hard I try, objectivity seems almost impossible. It is probably the same with some empirical studies, in which "non-mentalists," "objectivists," "behaviorists," or scientists form their hypotheses in advance, then try as hard as they can to prove them right by

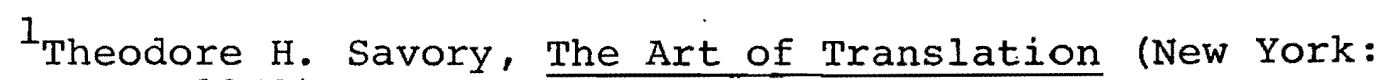
Alden Press, 1959), p. 76 . 
fitting the data and all other aspects of the study into their preconceived notions. Indeed, one can deal on many different levels in explaining the problems of translation; but what was very significant for me was to realize that the languages involved are made up of a unique total of cultural ties and philosophies. Perhaps, then, any language can only be completely understood, in parts at least, in its original form.

A translator must know both languages fluently. But unfortunately (or sometimes fortunately) he does not have the equivalent of all the components of one language in the second. Many times a term, a concept, or a word does not make sense in another language: consequently, the translator cannot totally duplicate the original. A translator partially observes, reads, or hears something in one language, and if there is no equivalent in the second language, he tries to give his own interpretation of the original in the second language. Therefore, the translator is at times exposed to the same, or very similar concepts, and at other times he is faced with a concept, word, or term that has no basis in another language. That concept is thus difficult or perhaps impossible to convey. This non-equivalence can occur in either direction between the first and second language.

In this translation I have had these same problems. Translation is interpretation, but interpretation is not 
was allotted to payment of salaries, the average employee received less than $\$ 100$ a month. 6

3. Pursuit of a negative political equilibrium.

Mossedeq tells how political equilibrium can take

place in Iran:

In my opinion, political equilibrium will take place in this country only when there are free elections. Negative equilibrium does not mean that any government will bring all its fans to the Majlis. Negative equilibrium, however, means that the government should not interfere with elections. The law of elections will be revised, which means that truly elected men get into the Majlis. That is when political equilibrium is achieved. Under this political equilibrium, the problems of foreign governments, not with one but with all, will solve themselves. 7

In a speech given in the Majlis on December 2, 1945, entitled "The Prevention of Issuing Oil Concessions," Mossedeq said:

Whatever I have said is in the best interests of a country and its government that are seeking political balance. If we pursue "positive politics," however, we must give a 92-year concession for the northern oil to achieve political balance (giving the southern oil to England and the northern to Russia). The people of Iran have never agreed, and now the Majlis disagrees about giving any oil concessions. A concession is much like a person who has lost one arm and now for the sake of better balance is willing to have the other arm cut off as well: a one-armed person is most likely in favor of

${ }^{6}$ H. B. Sharabi, Governments and Politics of the Middle East in the Twentieth Century (Princeton, N.J.: Van Nostrand, 1962), pp. 78-79.

$7_{\text {Historical Speeches, }}$ p. 35 (my translation). 
always translation. Movazene Manfi in the Farsi language, literally translated, is "negative balance." But Richard W. Cottam notes that this English translation

sounds like the doctrine of an irrational fanatic, and since this was the image of Dr. Mossedeq in many Western minds the phrase was interpreted literally. In fact, however, responsible Iranians have never held such an idea. 2

How can I explain the concept of "negative equilibrium" the way Mossedeq meant it in his language (Farsi)? In English positivist philosophy there is no basis, use, liking, acceptance, or tolerance for negativism.

The word negative prejudices the English reader before he even finishes the sentence. What Mossedeq meant by negative in the Third World is the most positive phenomenon ... or should I expect an American with all his material comfort, or an Englishman with his positive philosophy, to look at things as would a man from the Third World?

What Mossedeq is all about, what he devoted his total being to, and why he is great is that he popularized the concept and philosophy of the Third World, that of a "negative equilibrium." What he said in these two words to the Third World (and to his own people, who now appreciate him after many years, as the literature of intellectuals and

${ }^{2}$ Cottam, p. 202 
students all over the world demonstrates ${ }^{3}$ has a world of positivism in it. Because the man from the Third World knows that through "negative equilibrium" he gets back, he receives, he achieves, he collects, he gains what is his. right and belongs to him, but what has been denied him. obviously, getting, receiving, achieving, collecting, and gaining are all very "positive" concepts in English, but if I say "negative equilibrium," still the English reader will immediately think of a negative rather than a positive concept.

It took me so much explanation to say negative in the first language means positive in the second language, but to what degree have I succeeded? How well I have translated is not how well I have converted words and sentences, but how well I have conveyed the deeper concepts.

A perfect translation may be made from a short, easily understood writing. However, there are certain losses which occur in the connotative aspects of the work. It may lose some of the hidden qualities recognizable only in the original language.

The more one enters into the spirit of the language he is reading, the more he appreciates the responsibilities of

${ }^{3}$ Mossedeg and Negative Equilibrium: A Discussion on Iran's National Movement Philosophy (Berkeley: Followers of the Third National Front, 1971), p. 39. 
the translator, and realizes that many times it is impossible to bring over into English the heart of the original construction. As Herbert $C$. Tolman states in The Art of Translating,

Just as the eye of the artist, which by training enters more deeply into the soul of nature, realizes more than the inexperienced eye the difficulty of the task, and is more keenly aware of the powerlessness of the brush to portray all that is in the landscape, so the trained translator appreciates how exacting is his art. 4

Keeping in mind the exactness of the art of translation, as a translator one finds two major problem areas: First, conceptualization, or trying to portray the original concept as closely as possible, without getting mixed in the second area, mechanics, which requires following the text, word by word; as closely as possible.

We have already seen an example of the problem of conveying certain deeper concepts from Farsi to English. As for the second problem, when the translator keeps too closely to the text, he creates a mere mechanical reproduction. This "style" could be traced to the positivist tradition which still prevails in many universities, and provides us with bilingual publications that are distinguished by the dullness of the English versions. Although such

${ }^{4}$ Herbert C. Tolman, The Art of Translating (Boston: B. H. Sanborn, 1901), p. 20 . 
translations are accurate, this accuracy is only in the meaning, not the spirit of the work.

The difficulty of word-by-word translation is illustrated by the Farsi word Tazahor. It has only the equivalent "demonstration" in English, which has negative political overtones of violence and destruction not shared by the original. When Mossedeq used Tazahor in his speech, he was talking about his hopes that the people who were listening would express their opinions, voice their demands, and exercise their constitutional rights and freedoms for the betterment of their country. His usage thus connotes peace and constructivism. Perhaps the best translations are the result of the work of translators who consciously blend and balance these polar phenomena. 
Mohammed Mossedeq was born in Tehran in 1879 into the highest level of Iranian society. His family were landowners, and his father, Mirza Hedayat, was a minister of the court. His mother, Lady Najmol-Saltaneh, was related to the royal Qajar family.

After graduating from high school, Mossedeq became, at the age of seventeen, treasurer of the Khurassan province. This early political experience left him very disappointed at the corruption in government; consequently, he returned to Tehran to take courses in a new school for government officials. Going to Paris for further studies, Mossedeq in 1906 received a diploma from the Ecole des Sciences Politiques. He then studied at the University of Liege in Belgium and at the University of Neuchatel in Switzerland, where he earned a Doctorate in Jurisprudence in 1914.1

With his dedication, determination, family background, and education, Mossedeq was a logical candidate for the Majlis, the Iranian Houses of Parliament, to which he was

$1_{\text {Makan, p. }} 5$. 
elected in 1915 (the third Majlis). From 1915 to 1917, Mossedeq served on a committee that was studying the reorganization of the Ministry of Finance. He held a high post in the Ministry of Justice from 1918 to 1919.

In 1920, Mossedeq served as Governor-General in the province of Fars (Shiraz City), and in 1921, the first year Reza Khan was Minister of War, he was Minister of Finance in the cabinet of Qavam. In 1922, Mossedeq was GovernorGeneral of the province of Azarbaijan, whose Minister of Foreign Affairs he became in 1923.

From 1924 to 1928 Mossedeg served as an elected deputy from Tehran to the fifth and sixth Majlis. In 1925, as the outspoken leader of three other deputies, he debated against the passage of a bill to depose of the Qajar dynasty and to establish then Prime Minister Reza Pahlavi as Shah.

In this debate he made a very lengthy speech stating that the fundamental laws of the country must be preserved. He insisted that these laws would be destroyed if the gajar were removed and Reza Khan put in their place, adding that Reza Khan had been an effective prime minister, but that as Shah he might become a dictator. And he warned, "there is no nation that has achieved any status under a dictatorship." 2

${ }^{2}$ A Collection of Mossedeq's Historical Speeches (n.p.: Organizations of the Iranian National Front in Europe, 1967), p. 15 (my translation). 
Mossedeq was reelected to the sixth Majlis, but Reza Shah saw to it that he was not elected to the seventh. In 1928, Reza Shah had Mossedeq first imprisoned and then banished to exile in Ahmadabad, an agricultural village owned by Mossedeq's family, about 100 kilometers from the capital. In 1936, Mossedeq spent a month in Berlin for medical treatment--he had suffered from poor health all his life--after which he returned to the village. He then spent a few years of enforced residence at Birjand in eastern Iran. In 1940, Mossedeq's son pleaded his father's case with Crown Prince Mohammed Reza. But the situation remained the same until 1941, when British and Russian troops occupied Iran: in August, Reza Shah abdicated and was succeeded by his 22-year-old son, Mohammed Reza Shah. Mossedeq, upon direct orders from the new Shah, was immediately informed that he was free to live wherever he pleased. Years later, Mossedeq remembered his subsequent visit with Mohammed Reza Shah:

I told the Shah, "I shall never forget the kindness you have done for me in releasing me from your father's imprisonment. I have something to say now that I have the chance." The Shah said, "Go ahead, please.". Then I proceeded: "You, Your Majesty, should not put yourself in the same category as your father, as you will go bankrupt." The Shah said, "How will I go bankrupt?" I said, "Because your father has done things in this country that have caused him many enemies. It would be a wrong 
conclusion to say that anyone who was against your father is against you because you are both Shah." 3

Perhaps as a result of his own personal experience, Mossedeq; as the above quotation suggests, was always interested in the role of the Shah, especially as far as the government was concerned. On one occasion, Mossedeq justified his view that the Shah should not interfere in politics:

If a government position is available and ten people apply for it, then nine losers will become enemies of the Shah, and this number can be much greater in the case of choosing a deputy for the Majlis, since, say, only one out of 135 applicants is chosen. But if the Shah plays a neutral role, soon everyone will. respect him, as the Shah should be respected by all. England is a perfect example, for the king is removed from the running of government. If the English monarch did this, it wouldn't be so bad for you to do it. You may think only Churchill and Atlee run the government, but really there are many more qualified men running the government. If a country doesn't have honest politicians it doesn't have anything. . . I don't think anyone loves his country any more than you, but if you don't have able men around you', what will you accomplish? 4

Mossedeq consistently and strongly pursued his beliefs throughout his long political career. Basically, there were three major areas with which his government's policy was concerned:

i. Correction of all election laws.

3 Ibid., p. 109 (my translation).

${ }^{4}$ Ibid., p. 112 (my translation). 
Iran's bureaucratic inefficiency and red tape were notorious. Pro-western government officials were elected in a most corrupted way, and very seldom was anyone sent to the Majlis outside of the corrupt political machine.

Mossedeg once spoke humorously of such corrupt elections :

It is well known that after the seventh Majlis election, the late Moddaress (in one of the most religious, honest and dignified statements of the time) asked the chief of police, "In the sixth Majlis I had about fourteen thousand votes. This time (the seventh Majlis), I assume everyone was afraid of you and no one voted for me -- but I was wondering what happened to the one vote I gave myself?" 5

2. Fight against corruption and bribery within the government at all levels.

H. B. Sharabi, in Governments and Politics of The Middle East in The Twentieth Century, explains the situation:

Nepotism, bribery, and political favoritism are accepted as normal features of the administrative system. It was estimated that in the late $1950 \mathrm{~s}$ over 200,000 persons, or about 10 percent of the male urban population of Iran, were employed by the government: 50 percent of these were superfluous appointments made on the basis of political interest rather than on administrative requirement. Moreover, about 30 percent of the bureaucracy was considered illiterate. Although nearly 70 percent of the national budget (excluding military appropriations)

${ }^{5}$ Ibid., p. 14 (my translation). 
obtaining an artificial arm, if only for the sake of appearance. The one-armed person who wants his other arm cut off, however, would be better to give. up the misery of life and commit suicide instead.8

Mossedeq's opposition prevented his election to the fifteenth Majlis. He made known the responsible parties and went on a food strike that lasted four days. In the next election, Mossedeq was a successful candidate. The national front headed by Mossedeq was a minority in the Majlis. It consisted of seven deputies (out of 72), who made up a coalition of various political groups and parties (including the Tudeh, Iran's Communist Party). Despite his poor health, he was very active and took many bills to the Majlis, such as a bill to correct the election laws, a bill to rescind the Shah's ability to close down the Majlis, and bills to prevent martial law and guarantee freedom of speech and of the press. Of these bills, only that removing the Shah's power to close down the Majlis was not passed.

A bill to nationalize oil throughout Iran was taken to the Majlis on March 20, 1951, where it was passed successfully. After the oil nationalization, Mossedeq accepted the Iranian prime ministership, on condition that the Majlis would pass the "hands off" bill (the "hands off" bill proposed was the enforced departure of the Anglo-Iranian

${ }^{8}$ Ibid. 
Oil Company and the discontinuation of diplomatic relations with the British). ${ }^{9}$ Mossedeq then began his government's program of correcting Iran's election laws, described by Donald N. Wilber in Contemporary Iran:

Proposals for the reform of the electoral system were put forward. . . These proposals were not concerned alone with making electoral fraud more difficult, but also envisaged steps to insure a more responsible electorate and a more representative list of candidates. The specific suggestions included limiting the electorate to literates, limiting the number of candidates for each seat by requiring an advance deposit which would be forfeited by those receiving the smallest number of votes, and by holding countywide elections on the same days instead of for a period of weeks, thus preventing candidates from running in several districts. 10

There were many objections from the British government and its supporters within the country to Iran's nationalization of her oil resources. In October 1951, Britain took the matter to the International court in The Hague and later to the United Nations. Mossedeq personally appeared before both bodies. His claim was that it was not a case between two nations, but rather a case between a sovereign nation and a private oil company, and therefore not within the international court's jurisdiction. Mossedeq won his case at both courts.

When Mossedeq returned to Iran, the opposition, both

${ }^{9}$ Speeches of Dr. Mossedeg in the Sixteenth Majlis (n.p.: Mossedeq Publications, 1969), II, p. 136 .

10 Donald N. Wilber, Contemporary Iran (New York: Frederick A. Preager, 1963), p. 126 . 
from within and from without, was such that he resigned. But a bloody popular movement led to his return as prime minister. In addition, he took over the ministership of the Department of Defense.

Mossedeq was opposed by England, the United States, and by the Tudeh, each for its own motives. It is known that the Central Intelligence Agency, with the support of the United States government (and at a cost of 48 million dollars), planned a coup d'etat in secret. 11 In August of 1953, many of Mossedeq's followers were captured; he lost his leadership, was tried in military court, and then was sentenced to three years imprisonment.

In 1957, Mossedeq was released from prison and moved to Ahmadabad under parole. He died a natural death in 1969.

${ }^{11}$ A. Reza Arasteh, Man and Society in Iran (Leiden: E. J. Brill, 1964), p. 110. 
This speech. was given in the Majlis ten days before Mossedeq's resignation, which resulted in a people's uprising to put him back in power. Ironically, The Hague Tribunal's final decision regarding the controversy between Iran and the Anglo-Iranian Oil Company was announced on the same date (known as Si Tir in Iran). Mossedeq managed to return to power. In addition, he took over command of the Armed Forces, a role formerly exclusively the Shah's.

The persuasive power of this speech has great historical significance.

Honorable representatives, you are aware that foreign political pressure and domination for many years has deprived the people in our society of their freedom. We became so weak and hopeless ${ }^{2}$ that it was impossible to express an opinion or even verbally defend individual life and freedom. In this environment of fear, the bill for extension of the oil concession passed without protest. The Majlis had no choice. I must comment also on the lack of awareness shown by the Majlis as well as by the people of Iran. There was no chance of defeating the renewal of this horrible

${ }^{1}$ The Farsi text of this speech appears in M. Makan, A Look into the Life of Dr. Mohammed Mossedeg (n.p.: Iranian National Front in Europe, 1964), pp. 41-50.

2 zaboon and bichare were used, which have alternative meanings of "poor, "needy," "helpless," "remediless," "despicable." 
concession. Not only were the people unaware ${ }^{3}$ of the political disadvantages; but from the technical and the economical point of view, there was no chance for the people or their representatives to make a logical statement concerning the subject.

At all times, the ex-British oil company ${ }^{4}$ used its entire force to keep the people of Iran in total ignorance. This was its attitude from the very beginning until the day the company began discussing the renewal of its concession of 1933 for another thirty years.

In the same way, the company used its forces to deprive the people of any knowledge of their country's Godgiven ${ }^{5}$ wealth of oil. With such tactics, it was able to easily plunder this vast wealth. In other words, the company could leave the poor people with empty pockets while filling those of its greedy investors and capitalists. The unawareness and ignorance of the Iranians continued, and without hesitation, the ex-British oil company stole our national wealth until the fourteenth session of the Majlis. In the fourteenth Majlis, the Soviet Union found a good opportunity to ask for an oil concession in the northern part

3 Alame-beekhabari"the world of ignorance."

${ }^{4}$ Mossedeq always refers to this company as the "exBritish oil company," expressing the fact that it is no longer legal in Iran.

${ }^{5}$ See the chapter "Rhetorical Analysis" for Mossedeq's usage of "God." 
of the country. However, for the first time in the Majlis, the voice of the oppressed people of Iran started ringing in the ears of the people of the world.

$I^{6}$ attempted to make the most of this situation by stressing the disadvantages of giving the north's oil concession to the Russians. I also mentioned the loss resulting from the 1933 D'Arcy concession to the representatives in the Majlis. Furthermore, I reminded the members of the Majlis that this concession was brought to the Majlis, passed, and imposed upon the people at a time and place in history when there was no possibility of discussion and expression of opinions for the people or the representatives in the Majlis.

Most important of all was the fact that not one representative opposed the bill, and it passed immediately. Above all was the fact that the bill for helping teachers, although most of its content had already passed, was withdrawn at the suggestion of the Internal Revenue Secretary due to the hasty passage of the oil concession renewal. The verbal process has been recorded and is available to anyone. Also, note how they took advantage of the people's lack of awareness and the dictorial atmosphere. The concession renewal bill was passed quickly in the Majlis and

6 The pronoun "I" can be expressed many ways in Farsi. 
was forced upon the people. Although the Russian request for the northern oil concession was discussed in the Majlis no one pursued the matter, with the exception of a few legislators and editors of the press. One good thing did result from that situation: the people became more aware of their past carelessness. At least the people acquired some knowledge of oil. They realized the value of this national wealth and how freely they were losing it. You respectable representatives remember the combat and struggle and how during the extension of the fourteenth session of the Majlis the representatives were very concerned over the increasing awareness of the people. Gradually they were participating in their own destiny and learning to voice their opinions. With the new awareness of the people, the representatives to the Majlis began to worry about their reelection. Therefore, against constitutional law, they discussed the extension of the fourteenth Majlis. Not only was this a violation of the Constitution, it was against public opinion as well.

The first section of the Constitution provides that a new session of the Majlis will be postponed as long as foreign forces remain in Iran. My idea was to use the legal time for postponing the fifteenth Majlis and prolonging the fourteenth for two reasons. First, I wanted to correct the election process. Second, I did not want the new democratic freedom which was taking place in the Majlis to be 
interrupted, even for a short period of time. I kept waiting for one of the political parties or people seeking correction to say something or have some kind of demonstration. 7 During the last days of the fourteenth Majlis, a group of people from the left political party attacked and stopped the Majlis from continuing their work. This action occurred at exactly the same time that one of the representatives of the major world powers said that to improve relations with the government of Iran, he would be willing to speak with the governor of Qavam--not with anyone else (Qavamsolsaltaneh was the Prime Minister of Iran at the time).

The left parties became more confident--not that Qavam's government was in a position to make the oil deals with Russia--and they did whatever they could to insult or threaten the representatives of the fourteenth Majlis. The fourteenth Majlis failed to have a majority present at any time. A majority was not even present for the report of the Prime Minister on his trip to Moscow.

After the election of the fifteenth Majlis, a change in government occurred. The Prime Minister felt more assurance regarding candidates. There were many direct and indirect activities to stop the minorities, who were against

7 Unlike the Western concept "demonstration," which is a translation of the Farsi word, tazahor means "expressing one's opinion openly" and is not necessarily associated with violence. 
any concession of oil, which was about to be given in the Majlis. A few patriotic legislators were elected and found their way into the fifteenth Majlis. The representatives of the people of Iran were aware that all the misery of the people, whether in political or in economical matters, was because of the ex-British oil company. Consequently, public opinion was strongly provoked against the extortionist company. Furthermore, public opinion was provoked to the extent that despite all the finagling to ensure the passage of the concession, the bill still did not pass in the fifteenth Majlis. Also, with all the interest that the people of Tehran showed in the election for the sixteenth Majlis, they succeeded in sending their own representative to the sixteenth Majlis, which was clear evidence of their deep desire for cancellation of the imposed 1933 oil treaty. Certainly this eagerness existed throughout the country, but the result was not as evident as it was in the capital city of Tehran. This is not the time, however, to explain this.

The people of Tehran elected their own representative, with the idea that before or after the election for the sixteenth Majlis, they would be able to voice their opinions concerning their own destiny. A few people gathered together commenting on the fact that one must not forget the assistance the press and the mass media had given toward expressing public opinion. The strength they provided to 
this type of activity has continued until today. The national plant of the Iranians is almost full grown, and I hope to God that all the people of Iran will benefit from this as soon as possible. Therefore; anyone who says that popular demonstrations were against the interests of the country is terribly mistaken. 8 If the people had not gotten involved with political and social matters, the law nationalizing oil would never have passed, and no government would ever have objected to anything concerning the ex-British oil company. Whatever the government and the Majlis have done has been backed by public opinion. There was no doubt that the government and both Majlis (the shorayeh Melli and the Senate), when they are backed by the people, can talk, vote, and take steps for the interest of the country.

The day after the oil nationalization law was passed, I was asked to become the head of the government (Prime Minister). I accepted wholeheartedly, with a deep feeling of responsibility. The request had been made previously when I was a congressman, but I did not accept the position at that time because I considered myself more useful in the Majlis. I had come to the conclusion that the national struggle must start from the Majlis, which was my reason for rejecting the proposal of my being Prime Minister at

8 "Demonstration" (tazahor) as used in this context means a non-violent expression of the people for the betterment of the country. 
that time. Now the result of that struggle is visible and is becoming a reality. Both houses of the Majlis have performed their duty by enforcing the law in the manner prescribed by the law-makers. I could not keep still with the end of the road in sight and knowing how many had been involved with almost insurmountable problems. I was influenced also by the prospect of the enforcement of the law being placed in the hands of the weak, greedy, and selfish government under which the poor people of this country would not profit from their long struggle.

This was the only reason that I willingly accepted the difficult position of Prime Minister. I began to diagnose the work as any open-minded, intelligent, non-biased person would. I did not want the government or cabinet to have anything else in mind except what would be in the best interest of the country or the national wish. At the time, we needed a single aim uniting the country and providing internal peace. The smallest disagreement or episode could ruin the situation and create chaos. I chose reputable people from fine families with records of good health. These were people I was certain could help me in doing such an important task. Other corrections, such as social betterment, were certainly needed but could be acquired gradually in quieter times.

It is no exaggeration for the members of the Majlis to say that the ex-British oil company is the main reason for all 
the political, economical, and social problems in this country. It is a reality, and it is certain that if we sever the hands of this ex-British oil company from our country, no one person or government will be able to maintain the miserable condition of the past.

Today the people of Iran have awakened. When the result of this struggle is evident, I hope to God, with the present cooperation and unity, it will bring success. Not only will there be a hundred percent economic gain, but there will be twice as much non-material gain as well. It will bring awareness to the people and also make them take interest in their own future and destiny. No one can deny how important the people's awareness and involvement is for national government. When a nation is united and at the same time has a government by the people and for the people based on belief and ideology rather than fear and force, they will never be under the attack and domination of others. Today, if we have the ex-British oil company dominating and oppressing in political, economic, and social affairs of this nation, it is mainly because we have neglected to realize our national power and have surrendered with our hands tied.

In such important moments, God wanted the people to have the full scope of awareness and start walking in the path of truth. The Iranian people are awakened now, and they know the effect of a strong government backing up its 
oil corporation and threatening this nation with their guns. The nation of Iran is like a member of the world's family and has no other goal except peace. If a national uprising started, it would have one aim only--asking for peace. But it is impossible to base peace in the Middle East on the present situation, in which there would be constant danger of losing it. If the main aim or goal is to have the oil of Iran, as it was in the past, for the use of the free world, this also is our wish. We will do our best toward the same goal. Iran's government has said many times that we are legally responsible to do everything in our power to prevent any interruption in the sale of oil to our buyers.

My government ${ }^{9}$ has been willing to cooperate in ensuring proper oil distribution because we do not want any interruption in its sale. However, the ex-British oil company has started many uncooperative activities which interfere with this goal. Let the world know that Iran's government is not responsible for any interruption in the distribution of oil. We have done everything within our power to continue the work of the ex-British oil company. We even accepted their engineers with the same salary and the same benefits. We have enforced their rulings along with Iranian laws. We sacrificed as much as we could--we do not have any

9 "My government," dolat Injaheb, suggests, when translated into English, an overtone of ownership of government. However, as before, that is not the case in the original language. 
laws. We sacrificed as much as we could--we do not have any more to give. We feel certain that world public opinion has discovered this fact.

About the International Court at The Hague, I must say that Iran's government has always respected and obeyed the United Nations regulations. The government of Iran has backed this international institution to the fullest extent, and in the future, will always do the same. If this time the government of Iran did not listen to the forceful judgment of The Hague Tribunal, it is because we have repeatedly announced that the government of Iran has never signed a treaty or a concession with the government of England. Our opponent in this matter is a business corporation.

It is very surprising that The Hague Tribunal did not pay any attention to Iran's objection, and against the basic rules of judgment, did not pass any opinion on our national government. ${ }^{10}$ In this way, they have shaken the respect of the small nations for the International court of Justice. An international court must look to both strong and weak nations in the same manner. Such an international court comes into existence for the purpose of maintaining

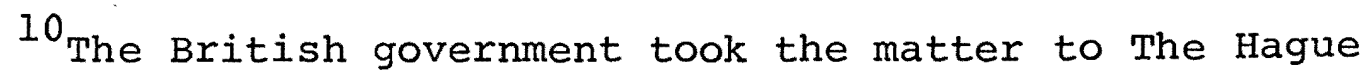
Tribunal. The court first passed judgment in England's favor, and only after Mossedeq's persistence did it retract its former decision, deciding "that it had no legal jurisdiction over the case" (John Marlowe, Iran [New York: Frederick A. Praeger, 1963], p. 96). 
peace in the world and to maintain justice, especially for the weaker countries. This kind of international justice court must follow a policy of equality for all nations, large and small. If the small nations do not believe in the fundamental justice of such an institution, only God knows what disastrous results may occur. According to the basic laws of national government in our country, we have the right to ask that certain merchants leave our country because they prevent political and economic independence. We will reimburse them fairly for any loss. This, being the basic right of any nation, has been written in the principles of the United Nations. Therefore, if we look at it on a realistic level, the denial of the judgment of the International Court of Justice shows our interest in these international institutions. Some of the nations of the world are doing their best to make the International Court of Justice look worthless and represent it as an instrument of evil to the people of the world, when the evil is really of their own doing.

I have definitely decided that with the backing of the people of Iran and of his Majesty the Shah, and with the support of both houses of the Majlis, according to the law, we cannot make the slightest move in the wrong direction. I will do my duty with all my strength and persistence. As long as I am traveling the difficult road that we have chosen and am encouraged and supported by public 
opinion, I am not afraid of any difficulty. I have no fear at all, even if the British government and the ex-British oil company, by using various means both within and outside of our country, are doing everything they can to overthrow my government. I will not weaken in this struggle. I am certain that it has arrived at a point where it must continue in the natural way until it reaches its goal. Now I am very old--the sun of my life has reached the edge of the roof. Sooner or later I must go the way that everyone has to go--die.

However, whether I am dead or alive, I hope, in fact I am certain, that the fire that has started will not die and will kindle a spark in the men of this country to pursue the national struggle until they acguire the desired result. If we don't have freedom of action in our home and foreigners dominate us with a rope around our neck pulling us to whichever side they wish, death is preferable to such a life. The people of Iran, with such a brilliant historical past and all they have done for the culture and civilization of the world, will never tolerate such a situation. Today our people have started a vast struggle, and no one is unaware of its importance. In this type of social movement, of course, one must be strong and ready to suffer many deprivations. No struggle, regardless how 
small, will be successful unless we work hard. Unless we do our best, we will accomplish nothing. ${ }^{11}$

For many years I have suffered from poor health and have learned that there are two kinds of cures. There are cures that deal with, the origin of the sickness and also cures for the result. Applying this theory to the problems of our country, I have proposed two categories which should manifest a cure for the "sickness" of our country. One of them is enforcement of the oil nationalization law and banishment of the ex-British oil company, because it is a form of corruption against everyone. To achieve this goal we h we have done everything possible. There have been government agents and members of special commissions appointed. So far there have been no mistakes, and we are very hopeful this will continue until we achieve the greatest possible success.

The second basic cure, in my opinion, is to correct our election laws. A bill has been prepared and proposed to the Majlis, and passing that bill is what the people expect. of course, experienced representatives will participate in discussions regarding this bill. Their function is to protect the rights of the people. Future governments must conform to the new election laws, and the representatives

$11_{\text {This }}$ paragraph was underscored by the translator. It is frequently used by Mossedeq's followers as a slogan. 
of the people have the responsibility of enforcing the constitution, thus assuring Iran of a democratic form of government.

This government under no circumstances is willing to intervene in future elections; and as long as the oil situation is not settled this government will remain in power. Even though I am weak, I will not step aside [the representatives shouted, "Well done!"] unless both Majlis should request that I do so. As long as this hasn't occurred, I will remain until the conclusion of the oil business. If (God forbid) the oil business has not been settled by the date set. for the next election, the government will bring a bill to the Majlis to delay the elections. In this way, we ensure no interruption in the oil proceedings. Dear sirs, if (God forbid) the situation regarding oil is prolonged to that point, there must be a delay in the election. Be assured, however, that this government will bring a bill to the Majlis, and if you gentlemen vote on it, of course the election will be delayed. [At this point Shoushtary commented, "Why do you bring 'if' into the situation?"] Because anyone can only be certain at the utmost of what he is doing, and I cannot trust the international situation. [Deputies: "You're right!"]

Although it is essential to deal with the cause of an illness, it is sometimes imperative to do whatever is necessary at the present moment for the general well-being 
of the sick person. One of the ways that our opponent has chosen to bring us to our knees and stop us from destroying the cause of the sickness of our country is to create problems for our national budget and our country's economy.

One problem regarding economy is the money exchange. This is due to the fact that we have not received any money from the ex-British oil company. The Iranian National Bank has reminded me of the situation by letter, and they have done a few things to eliminate the money exchange problem.

The bank has directed the government's attention to this depression of foreign exchange and especially to imports. After discussing the matter with the experts, a bill has been prepared which will provide a large part of the necessary imports for the country. The transfer of guaranteed funds outside the country is a most appropriate thing to do, all things considered.

Another problem concerns the nationalization of oil, the enforcement of the law regarding this and maintaining the vast refinery until normal business is resumed with our previous customers. This is essential in order to reach our ultimate national desire. We must be prepared to sacrifice. One of the important duties of every member of this nation is to help the national budget of the government as much as they can.

Fortunately, the people of Iran, with all the patriotic emotion they have displayed in recent times, have proven 
their loyalty to the government in time of disaster. In turn, the government has been worthy of their trust. As we have seen from the beginning of the deportation of foreigners, under the "hands off" policy, many ambitious people have willingly given all they had to the government. They have offered everything, and this government with gratitude has said, "Not yet, wait until we really need your help and we will utilize these individuals and groups." Until, the start of the oil sale to our foreign customers, we must provide budgets for all expenses. Right now our government income is not enough. With the trust that we have in the faithfulness of the public, there is a bill written enabling us to borrow the amount of two billion rials. 12

To overcome the problem resulting from lack of employment we must do something immediately. Therefore, after long discussions with the Import-Export Bank of the United States, we have again discussed a credit in the amount of 25 million for 15 years. This money would be used for agricultural machinery and road building. We must act upon this matter as soon as possible. By selling and distributing the agricultural machinery among our farmers, different types of crops can be harvested. It should reduce the volume of imported sugar and add to the level of our cotton

${ }^{12}$ The equivalent of approximately $2-1 / 2$ million dollars. 
exports as well as other agricultural products. It should make us very happy that this credit from the U. S. ImportExport Bank is not going to be spent for nonproductive materials, such as armaments. It will be spent for things that benefit the people, and as a result will considerably expand our total production level.

Even though it seemed essential to rush these bills through, you representatives should have enough time to study these subjects. Therefore, no pressure had been exercised to pass these bills. They have been offered to the Majlis in the regular way. Of course, the government expects a decision as soon as possible in order to achieve our goal. However, it depends upon factors such as the people's will and also that they do their best to carry it out. Another important element is that foreigners will be unable to do anything to ruin our work or destroy our unity. We must unite and not allow our deceitful opponent to get what he wants. You may be sure that the free world is backing us all the way, and that the name of Iran is held in the highest esteem.

In conclusion, I wish to relate a personal experience of some 50 years ago with men who had no conception of politics. Near the town of Qualeh Morqui was some Iand I had inherited; the land next to it was called Gi. We had experienced some land disagreements. In my state then were two groups of peasants or farmers who were antagonistic 
toward each other. If one day I assigned one group to do certain work, the other group would not go to work--until the time we had some disagreements with our neighbor. We had a discussion and the farmers from both groups said, "Previously when the landlord told us to do some work in our village, because of our antagonism, one group would go to work and the other would not. But that was in our own village. Now this disagreement is outside of our village, and the village is the base of our life. So we must unite, and following the order of the landlord, go and fight."

When peasants who know nothing about politics and who are disagreeing among themselves can have such a sincere feeling of unity and togetherness, the same things can be experienced by other groups. We must not expect the two houses of the Majlis, the Shorayeh Melli and the Senate, and also the press in this country, not to verbalize their internal problems. However, when the government has a disagreement with some foreign power, it should be the right and privilege of everyone to unite with his government.

I do not say that in this government there are no mistakes, but it is our task to correct those errors. If we succeed in this task, the people of Iran will be able to accomplish anything.

Improvements require money. Much of the time of this government is spent on things resulting from unemployment. For example, a great deal of time was spent on the factories 
of Isfahan and Azarbaijan because they were closed down. Any improvement requires money, and this problem is not solved by eliminating a few employees or transferring them from one place to another. If you have credit and capital, plan the production expenses within the country's budget and put the people to work. As soon as possible, the people will leave government work and start other enterprises. People today want to get a job with the government because of poverty.

We have collected many documents concerning the interference of the ex-British oil company. It has dominated our political and social life and committed many other wrongs. If one day the government of England takes Iran to the United Nations and registers a complaint, that day these documents will prove how much the ex-corporation has done against this country's internal affairs and how it has ruined our lives. At such a time, the free nations of the world will know the truth, and they can better judge the situation. Those documents are not provided to our fellow countrymen. If England should take us before the United Nations, then we can submit them to let all the world know the position of this poor nation (Iran). In 50 years Iran has lost everything to this ex-company. Anyway, dear sirs, these documents are not collected for the people of this country. 
I say it's good if you gentlemen do not mention the matters which bring disagreement among us in the Majlis. of course I do not want to say that because the oil situation is in process we must do wrong things. We must do the right thing as well as doing all we can for the oil situation--go forward. [Shoushtary interjected a comment, "Dear Doctor, disagreement is bad. Stop the reason for it."]

No matter how much happens in this Majlis, all of the disagreement within the Majlis will serve the ex-British oil company. If you gentlemen agree, once or twice a week we can have the vice-secretaries of the different ministries gather in the Majlis to discuss their ideas with one another.

If you gentlemen have any opinions concerning improvements in your own locality, I have no objection whatsoever. I want to see these things done, but gentlemen, please do not disturb the Majlis. In the Majlis everyone should totally support the government. If at any time you should decide that this government should not remain, first discuss it and then with one vote you can get rid of the government. Personally, God knows, I would be very grateful to you because, with my illness, work is difficult. However, this is my national duty and inspires me to continue.

I am asking all the vice-ministers to gather any time they want in the Majlis and answer any questions you may have. If they do not convince you with their answers, you 
gentlemen can come directly to me. If I personally do not do anything about it, then go to the shoraye Melli and discuss those matters. If we do it in this way, first of all it will not take the Majlis' time needlessly. Secondly, you will not become famous among the people for objecting to this government which is struggling with the ex-British oil company or perhaps for doing something against the national government.

God knows whatever I have said, I said it for you, and not for myself. 


\section{CHAPTER V}

\section{RHETORICAL ANALYSIS}

To analyze Mohammed Mossedeq's rhetoric properly, one must understand the background and the environment thoroughly. For example, the translated speech was inspired in large part by the conflict between Iran and the oil interests of the British government. In addition, one must understand that there are several possible ways of performing a rhetorical analysis, all within the meaning of the word rhetoric. However, in a study with a limited scope such as this one, the rhetorical analysis, though of vital importance, has to be limited to a discussion of the major aspects of the speech under consideration.

There are very few English language sources on Mohammed Mossedeq which are not written by historians or political scientists. Unfortunately, in the available literature, the most important characteristics of the man have been ignored. In order to understand another culture, one must overcome one's own cultural boundaries. And this is rarely achieved, since language and culture are inseparable. Therefore, for the purpose of this study my research was done mainly from the original literature. 
The original Farsi materials by and large are of two types (since 1953). There is the collection of several volumes of the actual speeches taken from the press and the Majlis records, and there is the rhetoric of Mossedeq's devoted followers, which obviously is biased in his favor. However, in recent years Mossedeq's student followers have developed an intellectual approach to their own biases. That is, they have found a rationale for the movement Mohammed Mossedeq initiated.

One of the latest accomplishments of these students is their international model based on Mossedeq's philosophy. This model forms the basis for current discussion within the framework of nationalistic movements, which is most helpful for the present type of study, and, more important, for the awareness of the world.

Because Mossedeq's speeches involve many years, many different occasions, and many different subjects, it is impossible to choose one or several speeches to translate and come up with a just example of Mossedeq's rhetoric. However, the speech chosen for translation, taken from the period in which Mossedeq actually achieved some of his objectives, was selected for its concluding and summarizing merit as far as Mossedeq himself was concerned. There is a verified text of the speech, as well as recordings of it. This speech was delivered as most of Mossedeq's speeches 
were--partially prepared and partially extemporaneous.

All Mossedeq's speeches were delivered around the same philosophy and toward the same goal as this particular speech. Its purpose, both generally and specifically, was to bring political awareness to the people's representatives in the Majlis as well as to the public, by means of the mass media press and the national radio stations. Because there was no television at that time, the radio played a great role in getting his message to the public. 1

The speech also seems intended to convince and persuade the people and the nation as a whole, as well as the Third World nations, to be involved in choosing their own destiny. His purpose was, therefore, to inform people, to make them aware, then to persuade and convince them to act upon their principles. Unlike what we find in the views of some historians and political scientists, such as that Mossedeq did everything to keep himself in power, this speech shows that his purpose, in reality, was just the opposite. He portrays a humble, selfless type of person in this speech when he says,". . If you don't want to do this which seems right to me, you, the representatives of the people, can impeach my government and someone else can come and do the job." 2

In Iran, the national radio stations have been very popular as a media tool.

${ }^{2}$ Makan, p. 47. 
In classifying the speech, one should categorize it as policy forming and professional, rather than ceremonial or social. The speech begins by conveying the horrors of foreign domination with its lack of freedom, the most important ingredient of the people's life. Then the speaker deals with the mistakes of statesmen and governments which had yielded such terrible results. He explains to the immediate audience 3 just how much responsibility lay with the Majlis and how they, the audience, could have prevented all those mistakes by acting under Iran's policy regarding foreign powers within the country. The speech strongly specifies the losses that the people had to suffer because of their own lack of political awareness and, even more so, because of that of the dishonest representatives within the government. Not so much in this speech but in other speeches, 4 Mossedeq very openly admits the corruption of the government officials, or the so-called people's representatives, and its terrible consequences.

The chosen speech shows that the speaker has a deep political awareness and illustrates how clearly he could see the situation--specifically, how the Tudeh (Iran's Communist Party), the only well-organized political party that Iran has ever had, had obstructed the nationalistic

3 Although this speech was formally addressed to the members of the Majlis, it was also directed to the populace, who formed an audience outside the building and listened to the speech over loudspeakers.

${ }^{4}$ Speeches of Dr. Mossedeq in the Sixteenth Majlis, p. 9. 
goals by opposing both Mossedeq's nationalistic government and the minority in the Majlis. The speech explains that no matter how little was the awareness of a few people in the past, it had been extremely helpful to a nationalistic government. Consequently, how much better it would be for the people, the press, and the mass media to pursue those activities which help the nationalistic government. An early part of the speech establishes the thought that an awareness of political reality can only be advantageous for the people and the country.

One must note that Mossedeq, throughout his long life and political career, always was a law-abiding man who wanted to see that everything went according to the regulations. This was true until the very last moments of his life, when he began to support the ideology that people should get what is theirs by any means necessary. The speech in question comes when Mossedeq was younger, however, and therefore its constant theme is to act according to the constitution and other laws of the land for which so many good men were sacrificed.

The central theme of this speech deals with an historical analysis of what has happened, what is happening, and what will happen by pursuing certain policies. After establishing the historical facts and explaining what has happened politically, economically, and socially under a nonnationalistic policy that did not have the people's interest 
at heart, the speech relates the issue of the rights of the people to the present situation. Mossedeq explains that earlier his government had even been willing to go along with certain demands of foreign powers to show that he was only interested in getting the people their rights, not in imposing anything on other nations or their corporations.

The speaker, throughout his speech brings about an awareness that international courts of law are not necessarily always just institutions. It could very well be that The Hague Tribunal was not just in taking England's side and ignoring Iran's government, simply because England was a world power. And the government of England had no right backing a corporation that, as a private company, legally had nothing to do with them.

To explain how the government of Iran was justified in not recognizing The Hague decision as either just or unjust is simple. The matter should never even have been submitted to the International Court of Justice, since it was not within its legal jurisdiction. It would have been within the International Court's purview had it been a case of two sovereign nations having problems with one another; but it was instead the sovereign nation of Iran opposing a private oil company. Mossedeq's speech reached its climactic point and greatly excited his audience when he declared, first of all, that the British government had no right to take such a matter to the International Court, 
second, that it was not within the Court's jurisdiction, and finally, that it was the right of the government of Iran to refuse to accept the decision.

The speech had succeeded by this point at logically relating the seemingly isolated conflict between the private oil company, England, and the sovereign government of Iran to the international situation. Then the speech expresses how surprising it is to find such a mockery of justice within the International Court of Justice. It goes on to suggest that if these are the kinds of decisions made, then the peoples of the world, mainly the Third world, should not and will not trust such institutions in the future. Once these small nations recognize that the International court only takes the side of the world imperialists, then they will not believe in it any longer, which will be disastrous for the world peace. (In the end, however, Mossedeq, through his persistence, logic, and knowledge of international law, won.)

The speech concludes that it is unjust for people to be underdogs; when the people decide they can achieve their goals and assume their rights, then it is time for them to act accordingly and avoid the mistakes of others in the past. In other words, "where there is a means, there is a way" could very well express the level of political awareness that Mossedeq was trying to convey in his speech. 
The language of the speech creates a mood of sincerity, a tone of determination and belief in just principles. It moves the audience to the point that it doesn't really matter if the speaker is alive or dead, for it is the task which remains always important, it is the task which must be pursued. The speech stresses the importance of being aware of just principles and tries to persuade the audience to take action.

Persuasion, by means of force or threat, is not typical of Mossedeq. However, he used concrete objects, especially his cane, ${ }^{5}$ to stir the people and their representatives to feel the absolute necessity of the struggle against imperialism and how worthless life becomes without dignity and freedom, the most sacred parts of a man's Iife.

The main effect of the logic of this speech lies in the changing of a theoretical reality into a practical reality that is far more meaningful to the masses. Mossedeq's speeches cannot be ignored as far as technical and psychological appeals are concerned. The speech constantly reminds the audience of the speaker's as well as the people's interests, beliefs, motives, and desires.

${ }^{5}$ This writer observed on several occasions Mossedeq as he delivered a speech, at the highlight of which he would often point the cane at the audience or the sky. Many times to emphasize his illness and frailty, he would lean on it. 
More important, though, is that the speaker is highly aware of his audience as a Middle Eastern people who are constantIy relating on a highly emotional level with most matters of life. It is a well-known characteristic of the speaker that if it became necessary he would cry, faint, or actually become physically inoperative. Because Mossedeq was so deeply committed to whatever he said, emotional appeals played a very important part of his delivery.

Mossedeq's personal credentials at the time of the speech were a matter of divided opinion. His integrity and loyalty were not denied, and perhaps were even supported, by his opposition. His experience was also known and accepted in all camps. It was his judgment that was questioned by his opponents. But through his speech one comes to the conclusion that the speaker's judgment could not have been so far off if for half a century of experience he had proved his loyalty, honesty and integrity.

The language used in this speech is highly communicative for the speaker used a very simple, down-to-earth language. Only seldom would Mossedeq quote from the Koran or other highly accepted sources. However, he does make frequent reference to God, which has cultural and psychological significance for an Iranian. It-reinforces the speaker's ethics and religious beliefs, as well as his good standing with God, which is mutually accepted by the speaker 
and his audience. The language of Mossedeq is very direct and forceful; yet his choice of words and his sentence structure are very simple and easily understood. Although the nature of Farsi is to be very redundant, Mossedeq's speeches, even when he was dealing with highly technical material, were, for the most part, not at all boring. They were also well understood by his audiences, who were largeIy illiterate.

Due to the characteristics of his delivery, such as the way he communicated with his audience, his poise and gestures, as well as the simplicity of his articulation and his calm voice, 6 Mossedeq would draw a vast number of people outside the Majlis. They would listen to his words through the loudspeakers, applauding frequently, and it seemed that the crowd did not need to listen to every word, since everyone listening seemed to know exactly what he would say next. The immediate effect of the speech was often that the crowd would bodily carry him quite a distance after he appeared at the entrance to the Majlis. One must appreciate that the public support Mossedeq received had not been experienced by any Iranian statesman before this time.

Perhaps the most important part of rhetorical analysis

\footnotetext{
${ }^{6}$ Mossedeq was well-known for his steady, calm voice (except when he became highly emotional). This writer has three recorded speeches. It is interesting to note that it was the content of the speeches more than his vocal theatrics, which triggered reactions from the crowds.
} 
is the study of effect: whether there are ultimate or immediate effects of the speech. The effect of Mossedeq's speeches was quite unusual. For over a century no spokesman, statesman, politician, or ordinary man from the Middle East had been so effective in bringing an awareness and understanding of the international situation to the people, of whom the majority were very politically unaware, as well as to their representatives who were so corrupted. The effectiveness of Mossedeq's speeches was of such a high degree that by rhetoric alone was he able to gain the public support of Iran. Moreover, he was one of the father-initiators of the movement of the oppressed peoples of the world against imperialistic powers. Due in part to Mossedeq's long-range influence, more than fifty dominated nations, who were nothing more than colonies, in essence, have achieved their sovereignty.

This writer finds it difficult to form a value judgment of this speech or other speeches made over half a century by Mossedeq. However, it is evident that through his philosophy, speeches, and writings, Mossedeq was able to inspre the people to realize that before all else they must "become themselves" to succeed. It is not only in this one speech but in all of Mossedeq's speeches that such a deep theme comes clearly across: If the people do not have freedom on all levels, then death is preferable. 
Mossedeq convinced the people he wanted to convince; thus historically, he becomes very significant.

With his most basic human tool, his language, Mossedeq was highly successful. But his success in persuasion reflects not only rhetorical merit but also a high level of literary merit. After twenty years, history shows that what this man started in his speeches has not died or faded away with the speaker's death. He says in the very highlight of 'his speech, "whether I am dead or alive I hope, in fact I am certain, that this fire will never die away and that the awakened men of this country will pursue the national struggle until they achieve their goal." 7 As one young Iranian put it, "The life of thoughts does not end with the death of the thinker; thoughts make history and endure for centuries. Mossedeq through the school of Mossedeq and the school of Mossedeq through the followers of that school are alive forever." 8

\footnotetext{
7 Makan, p. 46 .

${ }^{8}$ Mossedeg and Negative Equilibrium, p. 39 (my translation)
} 


\section{CHAPTER VI}

\section{SUMMARY AND CONCLUSION}

In presenting the translation and analysis of a speech by Mohammed Mossedeq, we first introduced the subject and basic characteristics of the speech and then justified a study of this type by virtue of the misconceptions about Mossedeq held in Western societies. A short biography then dealt with Mossedeq's place in history and with the biographical significance of matters concerning him. The next chapter discussed how cultural and philosophical differences affect translation and how this translator had to face certain practical problems. The main body of this study, the translation, was then offered. It was, as previously mentioned, difficult to select a speech that would provide a true example of Mossedeq, who created and pursued the same philosophy with the same rhetoric for over half a century. In the "Rhetorical Analysis" chapter we attempted to systematically analyze Mossedeq's speech. In this conclusion, we intend to discuss Mossedeq's discourse, values, and uniqueness, which have affected not only Iranians but the whole Third World as well.

It is important to note that Mossedeq, from his early years, recognized the basic problems of his poor and 
deprived country. These problems were, as he mentioned many times throughout his career, first, the foreign powers (world imperialists, dominated by England), with their ruthlessness and their dishonest economic policies. Second was the total corruption within the Iranian government--bribery, dishonesty, and imperialistic dealings for personal gain of the ruling class against their own people. Third was the lack of awareness and education of his people, which made Mossedeq's task in combating the problem very difficult. As a solution for the first problem--imperialistic domination and interference with the internal affairs of a small nation--Mossedeq pursued the philosophy of negative equilibrium, in line with his feeling that political equilibrium is a necessity.

The first step Mossedeq took was the nationalization of all natural resources, mainly oil, throughout Iran, and the dismissing of all agents of foreign governments, mainly England's. As for the second problem--the corruption within his small country's ruling class--he, in contrast to the tradition of the ruling class of Iran, lived a very simple and absolutely honest life. He pursued a constant course of action, of which the highlight was the correction of the election laws on all levels. 'In doing so, he set an example himself. 
The third problem--the lack of political awareness and educątion of his people--is a very significant and complicated problem for any educator. Because of this lack, Mossedeq actually did many things he did not talk about, such as allowing the people more freedom of action, speech, and press than what might have seemed necessary at the time. He also allowed the mass media, particularly the press, and political groups of different camps to go to extremes and even criticize him personally. All of this helped improve the people's understanding and awareness by exposing many hidden problems.

Mossedeq's goal, specifically as well as generally, was the helping of non-privileged people, not only in Iran but in the entire Third World. Mossedeq was perhaps the best thing that has happened in contemporary history to the Iranian nation. Like many great men of the world, his unselfish, down-to-earth attitude is certainly worthy of recognition, especially since he was from the highest level of his society. In one of his speeches he said, ". . may God damn those who in these desperate days of our nation make a statue of me." 1

It is clear that not only did Mossedeq have a strong nationalistic attitude, having organized the philosophy of negative equilibrium based on rediscovering one's self through political and economical independence, he also had

${ }^{1}$ Mossedeg and Negative Equilibrium, p. 39 (my translation). 
a. universal outlook on the world situation. Mossedeq knew very well that socio-economic change, the struggle for freedom, dignity, and independence, is not only an Iranian problem but also that of the Third World. Thus, when he became Prime Minister of Iran, he sent a telegram to Iran's chief delegate to the Seventh Assembly of the United Nations, saying,

Because one of my government's basic foreign policies is to help nations who are struggling for their right of independence, when Morocco and Tunisia's problems are discussed in the United Nations, you are directly ordered to give any possible help to the deprived African nations who are asking for their sovereignty. Furthermore, since the mentioned countries do not have representatives in the United Nations, announce officially that Iran's government is wholeheartedly willing to have their innocent voice reach the ears of the world's people from the United Nations podium. (Signed) The prime Minister, Mohammed Mossedeq. October 14, 1952.2

Because of the misconceptions about Mossedeq in the West, many scholars look at the man from a different point of view. Most available English language sources are proimperialism and anti-Mossedeq. This makes a study of the present kind (which is biased toward Mossedeq) justified. For the most part, the final chapter of Mossedeq's political career is either not mentioned or misconstrued. The fact remains that after the oil nationalization, Mossedeq trusted the United States to assist his nationalistic government at least economically and to stop England, which at

${ }^{2}$ Ibid., p. 47 (my translation). 
that time had her gunboats pointed at Iran's shore on the Persian Gulf. The United States, instead, while giving superficial hopes to Mossedeq, in reality cut off all of Iran's foreign aid and gave an enormous amount of credit to England to buy all of the oil products she needed from the western hemisphere. And if that wasn't enough, the United states, through the C.I.A., then planned an illegal coup' d'etat to overthrow Mossedeq. With the help of the C.I.A., Iran's ruling class captured Mossedeq and placed him in prison.

In the final analysis, as biased as it seems, what condemns Mossedeq is what he fought for all his life. The mistakes Mossedeq is charged with are the trust he put in his friendly appearing enemies, in the corrupt ruling class of Iran, and in the United States government, which spoiled Mossedeq's dreams and, through the C.I.A. scandal, cost him his government. As far as the American government is concerned, my point is best made by Richard W. Cottam: ". - the paradox is that in the interest of combating communism, the United States has been pursuing a policy of economic determinism that might well produce not a Nasser but a Castro-type leadership." 3

In spite of all of these setbacks and problems,

${ }^{3}$ Cottam, p. 319 . 
Mossedeq, in half a century, motivated millions to begin the struggle for their freedom by non-violent means within the law. He acted upon whatever he said, and through his actions, he achieved the highest goal that he had wanted. He then said, "What else can I ask for, when in my own lifetime I see the struggle that we have started is now in progress, and people are pursuing what is their 'right, and the fire which has started will never die." 4

In Iran, a nation of 30 million people, more than 60 percent of the population live in rural areas, and more than 80. percent are illiterate. These, however, are fairly recent figures. Twenty years ago they were much higher and, in fact, the illiteracy and rural living patterns enabled the Western imperialists to dominate the country, thereby forcing their separatism policy successfully among the people. It was at this time and under these conditions that Mohammed Mossedeq managed to bring awareness and unity to his people in order that they would defeat the foreign powers within and without their country. Although these foreign powers gained back their role, by legal or illegal means, Mossedeq's ideology remains popular today not only among his people but a good portion of the Third World as well. lation).

${ }^{4}$ Mossedeg and Negative Equilibrium, p. 14 (my trans- 
Richard w. Cottam has probably done one of the most 0 objective studies concerning Iranian nationalism. He states,

- . Mossedeq had ceased being just another Nationalist leader. He had become the symbol of Iranian nationalism: anyone daring to strike at this symbol must suffer the consequences. 5

${ }^{5}$ Cottam, p. 154 .

\section{BIBLIOGRAPHY} Ache'son, Dean. Present at the Creation: My Years in the
State Department. New York: w. W. Norton, 1969.

A Collection of Mossedeq's Historical Speeches. n.p.: Organizations of the Iranian National Front in Europe, 1967.

Arasţeh, A. Reza, Man and Society in Iran. Leiden: E. J. Brill, 1964 .

Aristotle. Rhetoric. Translated by w. Rhys Roberts. New York: Modern Library, 1954.

Cottam, Richard w. Nationalism in Iran. Pittsburgh: University of Pittsburgh Press, 1964.

Gilman, Wilbur E., Aly, Bower, and White, Hollis L. The Fundamentals of Speaking. 2nd ed. New York: Macmillan Company, 1968 .

Makan, M. A Look into the Life of Dr. Mohammed Mossedeg. n.p.: Iranian National Front in Europe, 1964

Malik, Charles. "The Near East: The Search for Truth." Foreign Affairs, January 1952, pp. 231-264.

"Man of the Year: Challenge of the East." Time, January 7 1952, pp. 18-21.

Marlowe, John. Iran. New York: Frederick A. Praeger, 1963.

Mossedeg and Negative Equilibrium: A Discussion on Iran' National Movement Philosophy. Berkeley: Followers of the Third National Front, 1971.

Savory, Theodore H. The Art of Translation. New York: Alden Press, $19 \overline{59 .}$

Sharabi, H. B. Governments and Politics of the Middle East in the Twentieth Century. Princeton, N.J.: Van Nostrand, 1962 . 
Speeches of Dr. Mossedeg in the Sixteenth Majlis. 2nd vol. n.p.: Mossedeq Publications, 1969.

Tolman, Herbert $C$. The Art of Translating. Boston:

B. H. Sanborn, 1901 .

Wilber, Donald N. Contemporary Iran. New York: Frederick A. Praeger, 1963. 